\title{
The distribution, abundance and population trends of gentoo, rockhopper and king penguins in the Falkland Islands
}

\author{
M. Bingham
}

The Falkland Islands are a globally important breeding location for seabirds, including penguins. The total breeding populations of three of the four main penguin species present in the Falklands were censused in the austral summer of 1995/96. The results for gentoo and rockhopper penguins suggest declines of about 43 and 90 per cent, respectively, since a similar census in 1932/33. Recent monitoring studies suggest that these declines are still continuing; research to investigate causes (which is likely to reflect changes in the marine, rather than terrestrial environment) is a high priority. In contrast, king penguin populations, currently c. 400 pairs, have increased steadily, by 700 per cent since 1980/81, in line with world-wide trends for this species.

\section{Introduction}

The Falkland Islands lie in the south-west Atlantic, approximately $450 \mathrm{~km}$ north-east of the southern tip of South America. The archipelago is made up of two main islands and several hundred smaller islands, which are home to large numbers of breeding seabirds, including penguins. The Falkland Islands have the world's largest breeding population of rockhopper penguins Eudyptes c. chrysocome, and the second largest population of gentoo penguins Pygoscelis papua (Croxall et al., 1984).

Data collected from breeding colonies in the Falklands during the past 10 years suggested a decline in the breeding populations of gentoo and rockhopper penguins (Bingham, 1995). The only comprehensive island-wide population census for these species was in 1932/33; a repeat census was needed to confirm whether declines were occurring throughout the islands, and to estimate their magnitude. In addition, the census would establish comprehensive baseline data to complement current monitoring studies. The imminent exploration for oil in Falklands' waters makes the establishment of baseline data for these species particularly important, because of their potential high vulnerability to oil pollution.
The Falklands' population of king penguin Aptenodytes patagonicus is very small, but was still included in the census. The fourth main Falklands' penguin, the magellanic penguin Spheniscus magellanicus, was not included in this census because of the difficulties of censusing a species that nests in burrows.

\section{Methods}

Most breeding-site locations were already known from fieldwork conducted prior to the 1995/96 census but this information was checked by extensive consultation with landowners to ensure that sites were not overlooked.

For a comprehensive census of such a large area, it was only possible to make a single visit to each site. Counts made during a single visit will inevitably underestimate the total number of breeding pairs, because of omitting pairs that have either not yet laid their eggs, or those that have already laid and subsequently failed. In general, counts were timed to correspond with the end of the egg-laying period, thereby ensuring that few pairs were still to lay, and allowing an assessment to be made of the underestimate due to pairs failing, by using failure 


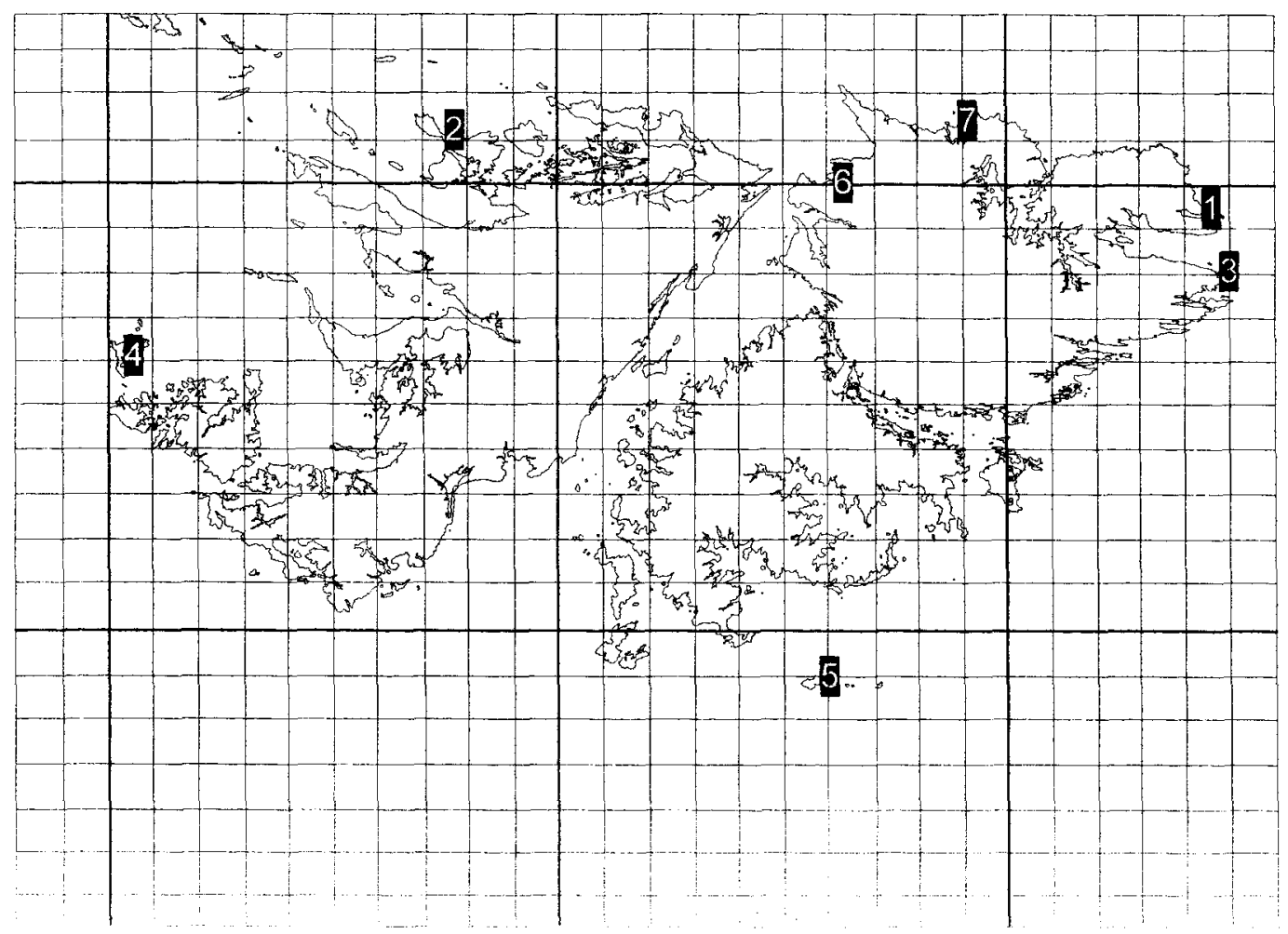

Figure 1. King penguin colony locations 1995/96.

rates during incubation from other studies.

The gentoo penguins concluded their first egg-laying by the end of October 1995. The 1995/96 census counted 15 per cent of the gentoo population between 15 and 31 October, and the remainder between 1 November and 1 December. Because gentoos failing early tend to re-lay, and failure rates during incubation are low (c. 1 per cent/week), the magnitude of any underestimates resulting from differences in survey dates should be well below 5 per cent.

Rockhopper penguins are much more synchronous in terms of egg-laying than gentoo penguins. Laying was concluded by midNovember 1995, and the $1995 / 96$ census counted 98 per cent of the rockhopper population between 1 November and 1 December ( 2 per cent between 2 and 18 December). Repeated counts of rockhopper colonies in previous years showed that nest counts drop at a rate of about 3 per cent per week for the first month after egg-laying, as a result of failed nests. It is therefore unlikely that the average underestimate of rockhopper populations exceeded 10 per cent.

For most rockhopper and all gentoo breeding sites, the recorder made two separate counts of all occupied nests using a tally counter. The mean of the two counts was taken as the number of breeding pairs. Where these two counts differed by more than 10 per cent, a

Table 1. King penguin colony counts 1995/96

\begin{tabular}{llcc}
\hline & Site & Date & No. chicks \\
\hline 1 & Volunteer Point & $11 / 11 / 95$ & 330 \\
2 & Saunders Island & $01 / 12 / 95$ & 3 \\
3 & Kidney Cove & $28 / 10 / 95$ & 2 \\
4 & New Island & $01 / 12 / 95$ & 1 \\
5 & Sea Lion Island & $12 / 11 / 95$ & 1 \\
6 & Paloma Beach & $12 / 11 / 95$ & 1 \\
7 & Concordia Beach & $26 / 11 / 95$ & 1 \\
& & & 339 \\
\hline
\end{tabular}

(c) $1998 \mathrm{FFI}$, Oryx, 32 (3), 223-232 


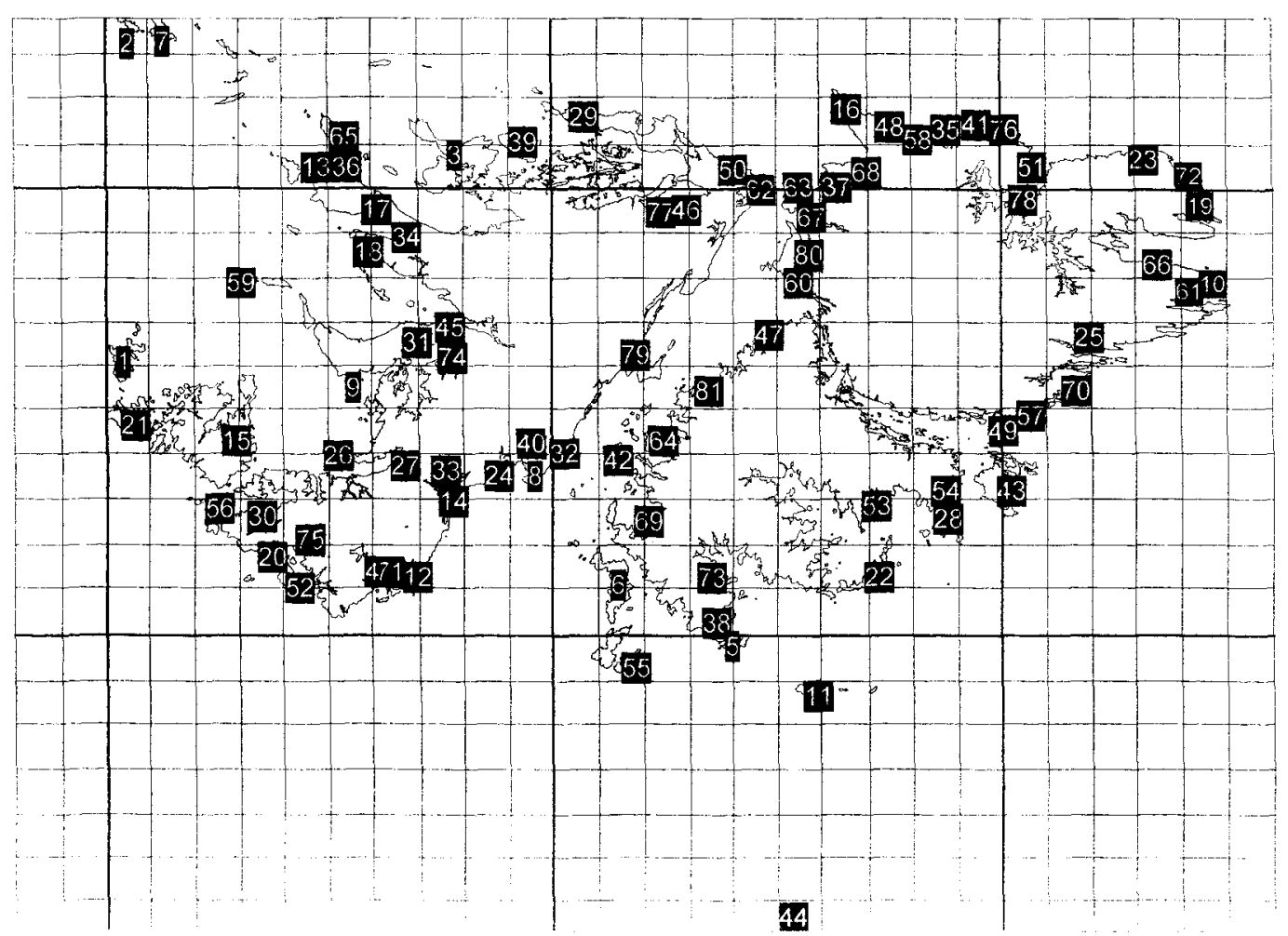

Figure 2. Gentoo penguin colony locations 1995/96.

third count was taken to give a mean value of three counts. In practice this was rarely necessary, and the spread of results was generally well within \pm 5 per cent. Reference photographs were also taken at most sites for future comparisons.

For the very large rockhopper colonies on Steeple Jason, Grand Jason, Bird Island and Beauchene Island, direct ground counts were not possible. These sites were counted using a total of 60 randomly selected sample plots to determine the range of nesting densities, and the areas of the colonies were determined, to enable estimates of total breeding pairs. A minimum of 10 per cent and a maximum of 15 per cent of the total colony area was sampled at each of the three sites. These measurements of area and density taken during the site visits were later compared against aerial photographs taken of the colonies. The margin of error for this methodology is greater than for direct counts, but should be within \pm 10 per cent.

(C) 1998 FFI, Oryx, 32 (3), 223-232
The breeding cycle of the king penguin is different from that of gentoos and rockhoppers, with chicks over-wintering at the colony, and a complete breeding cycle lasting over a year. This tends to result in individual birds having their following breeding cycle out of phase with its predecessor; thus large chicks and eggs may both occur in a colony at the same time. This complicates assessment of the breeding populations so chick counts were taken instead. The estimation of error for chick counts is well below 5 per cent, but will underestimate the number of breeding pairs by about 20 per cent (Lewis Smith and Tallowin, 1979).

\section{Results}

\section{King penguin}

The 1995/96 census recorded a total of 339 chicks for the Falklands as a whole (Table 1; 


\section{BINGHAM}

Figure 1). Allowing for losses during incubation and chick-rearing, and the staggered breeding cycle, this figure gives an estimated Falklands population of around 400 breeding pairs. Volunteer Point, on the north-east coast of East Falkland, was the only king penguin breeding colony in the Falkland Islands, with individual pairs breeding in gentoo colonies at all other sites.

\section{Gentoo penguin}

The $1995 / 96$ population of gentoo penguins in the Falkland Islands was about 65,000 breeding pairs (Table 2; Figure 2), with an estimated range of $61,750-68,250$ pairs. There was a total of 81 breeding sites distributed throughout the archipelago, ranging in size from 7 to 5100 breeding pairs. Eighteen sites had breeding

Table 2. Gentoo penguin colony counts $1995 / 96$

\begin{tabular}{|c|c|c|c|c|c|c|c|}
\hline & Site & Date & No. nests & & Site & Date & No. nests \\
\hline 1 & New Island & $01 / 12 / 95$ & 5,100 & 43 & Lively Island & $30 / 10 / 95$ & 490 \\
\hline 2 & Steeple Jason Island & $11 / 11 / 95$ & 3,923 & 44 & Beauchene Island & $28 / 11 / 95$ & 444 \\
\hline 3 & Saunders Island & $01 / 12 / 95$ & 3,510 & 45 & Town Point & $13 / 11 / 95$ & 416 \\
\hline 4 & Albemarle & $05 / 11 / 95$ & 2,626 & 46 & Gladstone Valley & $03 / 12 / 95$ & 410 \\
\hline 5 & Bull Point & $02 / 11 / 95$ & 2,230 & 47 & New Haven & $05 / 11 / 95$ & 400 \\
\hline 6 & Speedwell Island & $21 / 11 / 95$ & 2,229 & 48 & North Pond & $19 / 11 / 95$ & 379 \\
\hline 7 & Grand Jason Island & $09 / 11 / 95$ & 2,196 & 49 & Fox Point & $31 / 10 / 95$ & 378 \\
\hline 8 & Carcass Bay & $08 / 11 / 95$ & 2,039 & 50 & Little Mountain & $01 / 12 / 95$ & 375 \\
\hline 9 & Shallow Bluff & $14 / 11 / 95$ & 1,737 & 51 & Brazo del Mar & $24 / 11 / 95$ & 357 \\
\hline 10 & Kidney Cove & $28 / 10 / 95$ & 1,730 & 52 & Ten Shilling Bay & $02 / 11 / 95$ & 342 \\
\hline 11 & Sea Lion Island & $12 / 11 / 95$ & 1,484 & 53 & Bluff Head & $01 / 11 / 95$ & 330 \\
\hline 12 & Lucas Hill & $07 / 11 / 95$ & 1,457 & 54 & The Sandhills & $16 / 12 / 95$ & 330 \\
\hline 13 & Grave Cove & $20 / 11 / 95$ & 1,434 & 55 & Barren Island & $01 / 11 / 95$ & 326 \\
\hline 14 & Port Edgar & $15 / 10 / 95$ & 1,408 & 56 & Cape Orford & $03 / 11 / 95$ & 311 \\
\hline 15 & Weddell Island & $22 / 11 / 95$ & 1,220 & 57 & Berthas Beach & $31 / 10 / 95$ & 310 \\
\hline 16 & Cape Dolphin & $19 / 11 / 95$ & 1,148 & 58 & Little Creek & $19 / 11 / 95$ & 304 \\
\hline 17 & Stevelly Bay & $23 / 11 / 95$ & 1,071 & 59 & 4th Passage Island & $18 / 12 / 95$ & 300 \\
\hline 18 & Whaler Bay & $27 / 10 / 95$ & 1,000 & 60 & Rookery Point & $30 / 11 / 95$ & 300 \\
\hline 19 & Volunteer Point & $11 / 11 / 95$ & 970 & 61 & Sparrow Cove & $28 / 10 / 95$ & 300 \\
\hline 20 & Stephen's Peak & $02 / 11 / 95$ & 894 & 62 & Leopard Bay & $03 / 12 / 95$ & 270 \\
\hline 21 & Beaver Island & $27 / 10 / 95$ & 892 & 63 & Rookery Sands & $17 / 11 / 95$ & 249 \\
\hline 22 & Bleaker Island & $31 / 10 / 95$ & 875 & 64 & Port King & $05 / 11 / 95$ & 208 \\
\hline 23 & Seal Bay & $03 / 11 / 95$ & 875 & 65 & Carcass Island & $03 / 11 / 95$ & 180 \\
\hline 24 & West Head & $28 / 10 / 95$ & 855 & 66 & Strike off Point & $14 / 11 / 95$ & 176 \\
\hline 25 & Bluff Cove & $02 / 12 / 95$ & 850 & 67 & Fanning Harbour & $17 / 11 / 95$ & 160 \\
\hline 26 & Queen Point & $09 / 11 / 95$ & 832 & 68 & Murdos Cove & $02 / 12 / 95$ & 137 \\
\hline 27 & Lake Hammond & $31 / 10 / 95$ & 830 & 69 & Moffit Harbour & $04 / 11 / 95$ & 130 \\
\hline 28 & Motley Point & $16 / 12 / 95$ & 800 & 70 & Pleasant Road & $11 / 12 / 95$ & 123 \\
\hline 29 & Pebble Island & $30 / 11 / 95$ & 754 & 71 & Rodeo Point & $08 / 11 / 95$ & 120 \\
\hline 30 & Fox Point & $03 / 11 / 95$ & 751 & 72 & Cow Bay & $11 / 11 / 95$ & 117 \\
\hline 31 & Isthmus Cove & $14 / 11 / 95$ & 738 & 73 & Salt House & $03 / 11 / 95$ & 110 \\
\hline 32 & Blue Mountain & $11 / 12 / 95$ & 728 & 74 & North Beach & $13 / 11 / 95$ & 103 \\
\hline 33 & Big Seal Rook & $29 / 10 / 95$ & 716 & 75 & Hoste Inlet & $04 / 11 / 95$ & 66 \\
\hline 34 & Port North & $24 / 11 / 95$ & 705 & 76 & Limpet Creek E & $26 / 11 / 95$ & 54 \\
\hline 35 & Concordia Beach & $26 / 11 / 95$ & 701 & 77 & Long Point & $04 / 12 / 95$ & 52 \\
\hline 36 & Hope Point & $20 / 11 / 95$ & 654 & 78 & Colorado Bay & $24 / 11 / 95$ & 44 \\
\hline 37 & Paloma Beach & $12 / 11 / 95$ & 601 & 79 & Shag Harbour & $12 / 12 / 95$ & 16 \\
\hline 38 & Bull Roads & $02 / 11 / 95$ & 564 & 80 & Ajax Bay & $30 / 11 / 95$ & 14 \\
\hline 39 & Keppel Island & $04 / 11 / 95$ & 560 & 81 & Egg Harbour & $05 / 11 / 95$ & 7 \\
\hline 40 & Bottomless Pond & $07 / 11 / 95$ & 534 & & & & \\
\hline 41 & Limpet Creek & $26 / 11 / 95$ & 531 & & Total & & 65,000 \\
\hline 42 & Great Island & $02 / 11 / 95$ & 490 & & & & \\
\hline
\end{tabular}




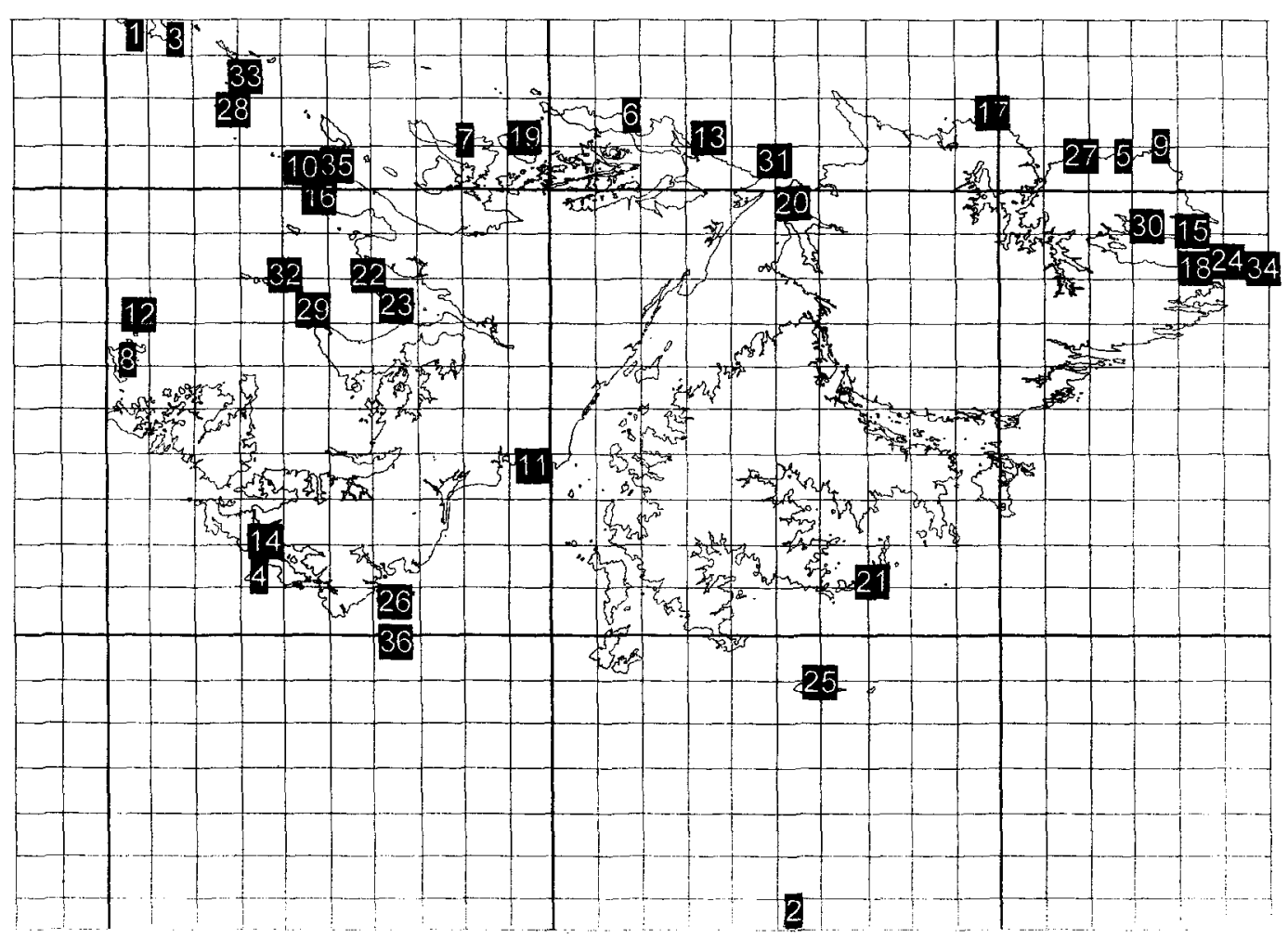

Figure 3. Rockhopper penguin colony locations 1995/96.

populations of $>1000$ pairs, between them totalling 58 per cent of the overall population. The general distribution was: East Falkland, 16,000 pairs (24.5 per cent); West Falkland, 24,000 pairs ( 37 per cent); and Outer Islands, 25,000 pairs ( 38.5 per cent).

\section{Rockhopper penguin}

The 1995/96 population estimate for rockhopper penguins in the Falkland Islands was 297,000 breeding pairs (Table 3; Figure 3), with an estimated range of $267,000-327,000$ pairs. There was a total of 36 breeding sites, ranging in size from 83 to 115,000 breeding pairs. These sites are distributed around most of the Falklands but the greatest concentrations are on the outer islands. The general distribution was: East Falkland, 21,000 pairs (7 per cent); West Falkland, 11,000 pairs ( 4 per cent); and Outer Islands, 265,000 pairs ( 89 per cent).

\section{Discussion}

\section{King penguin}

The present Falklands' population of c. 400 breeding pairs is almost entirely concentrated at one location on the north-east of East Falkland. This colony has expanded from 38 chicks in 1980/81 (Bingham, 1995) to 330 chicks in 1995/96. Nevertheless this comprises less than 0.1 per cent of a world population that has been increasing consistently since the 1970s (Woehler, 1993), and the high rate of increase in the Falklands during this period is likely to be due in part to immigration from the large and expanding population on South Georgia. At least one bird banded on South Georgia has been resighted in the Falklands ( $\mathrm{O}$. Olsen, pers comm). 


\section{Gentoo penguin}

The Falkland Islands are one of 12 major breeding sites for this species (Robertson, 1986). The 65,000 pairs in the Falklands are widely distributed throughout the archipelago, and represent about 20 per cent of the world population, second in size only to South Georgia. Within the Falklands there are three sites (New Island, Steeple Jason and Saunders Island) that each hold more than 1 per cent of

Table 3. Rockhopper penguin colony counts 1995/96

\begin{tabular}{|c|c|c|c|}
\hline & Site & Date & No. nests \\
\hline 1 & Steeple Jason Island & $09 / 11 / 95$ & 11,5000 \\
\hline 2 & Beauchene Island & $27 / 11 / 95$ & 7,4300 \\
\hline 3 & Grand Jason Island & $09 / 11 / 95$ & 3,4000 \\
\hline 4 & Bird Island & $23 / 11 / 95$ & 10,600 \\
\hline 5 & Rabbit Rincon & $05 / 11 / 95$ & 8,487 \\
\hline 6 & Pebble Island & $01 / 12 / 95$ & 6,702 \\
\hline 7 & Saunders Island & $01 / 12 / 95$ & 5,781 \\
\hline 8 & New Island & $01 / 12 / 95$ & 5,500 \\
\hline 9 & Macbride Head & $04 / 11 / 95$ & 4,146 \\
\hline 10 & West Point Island & $16 / 12 / 95$ & 4,042 \\
\hline 11 & Carcass Bay & $08 / 11 / 95$ & 3,783 \\
\hline 12 & North Island & $21 / 11 / 95$ & 3,472 \\
\hline 13 & Tamar Point & $02 / 12 / 95$ & 2,566 \\
\hline 14 & Stephens Peak & $02 / 11 / 95$ & 2,504 \\
\hline 15 & Rugged / Eagle Hill & $13 / 11 / 95$ & 2,460 \\
\hline 16 & Deaths Head & $21 / 11 / 95$ & 2,243 \\
\hline 17 & Cape Bougainville & $25 / 11 / 95$ & 1,943 \\
\hline 18 & Mount Low & $14 / 11 / 95$ & 1,910 \\
\hline 19 & Keppel Island & $05 / 11 / 95$ & 1,168 \\
\hline 20 & Fanning Head & $18 / 11 / 96$ & 1,071 \\
\hline 21 & Bleaker Island & $31 / 10 / 95$ & 700 \\
\hline 22 & Rabbit Island & $18 / 11 / 95$ & 600 \\
\hline 23 & Hummock Island & $18 / 11 / 95$ & 540 \\
\hline 24 & Cochon Island & $29 / 11 / 95$ & 515 \\
\hline 25 & Sea Lion Island & $12 / 11 / 95$ & 504 \\
\hline 26 & Arch East Island & $25 / 11 / 95$ & 411 \\
\hline 27 & Campa Menta & $25 / 11 / 95$ & 380 \\
\hline 28 & South Jason Island & $18 / 12 / 95$ & 300 \\
\hline 29 & Ist Passage Island & $19 / 11 / 95$ & 267 \\
\hline 30 & Diamond Cove & $14 / 11 / 95$ & 155 \\
\hline 31 & White Rock & $18 / 12 / 95$ & 150 \\
\hline 32 & 2nd Passage Island & $29 / 11 / 95$ & 125 \\
\hline 33 & Elephant Jason Island & $18 / 12 / 95$ & 100 \\
\hline 34 & Kidney Island & $25 / 11 / 95$ & 100 \\
\hline 35 & Grave Cove & $22 / 11 / 95$ & 93 \\
\hline \multirow[t]{2}{*}{36} & Clump Island & $25 / 11 / 95$ & 83 \\
\hline & Total & & 297,000 \\
\hline
\end{tabular}

the estimated world population of 318,000 pairs. However, comparison with Bennett's (1933) total of 116,000 pairs for the Falklands during 1932/33 (Table 4) suggests an overall decline of around 45 per cent.

Comparison of single years, widely separated in time, can sometimes be unreliable, especially in a species whose population shows considerable interannual fluctuation (Croxall and Rothery, 1995). However, population counts from 21 colonies, which have been monitored since 1988/89 (Figure 4; Falklands Conservation, unpublished data), show that the 1995/96 census did not coincide with a season of especially low population. Moreover, these data suggest that the decline has been continuing in recent years. Although no records exist as to the methodology employed during Bennett's (1933) census, his numerous publications testify to his reputation as a meticulous and experienced observer and naturalist, and gentoo penguins are a particularly easy species to count accurately. Even if the larger and hence more difficult sites such as the Jason Islands are excluded, comparable counts for the remaining sites still indicate a decline over the 60 -year period.

\section{Rockhopper penguin}

The Falklands population, of around 300,000 pairs, represents the world's most important breeding site for this species. In addition, the Falkland Islands have 63 per cent of the world population for this subspecies, with most of the remainder being on islands around the coast of Chile (Bingham and Mejias, in press). In the Falklands, the islands of Steeple Jason and Grand Jason to the north-west, and Beauchene to the south, hold the only very large concentrations ( $>20,000$ pairs) and these account for around 75 per cent of the Falklands' population.

Population counts from study sites monitored throughout the 1990s show that the $1995 / 96$ census did not coincide with a year of naturally low populations (Figure 5). Thus the current population estimate is very considerably lower than the $3,169,000$ pairs recorded by Bennett (1933) in 1932/33 (Table 5). Although 


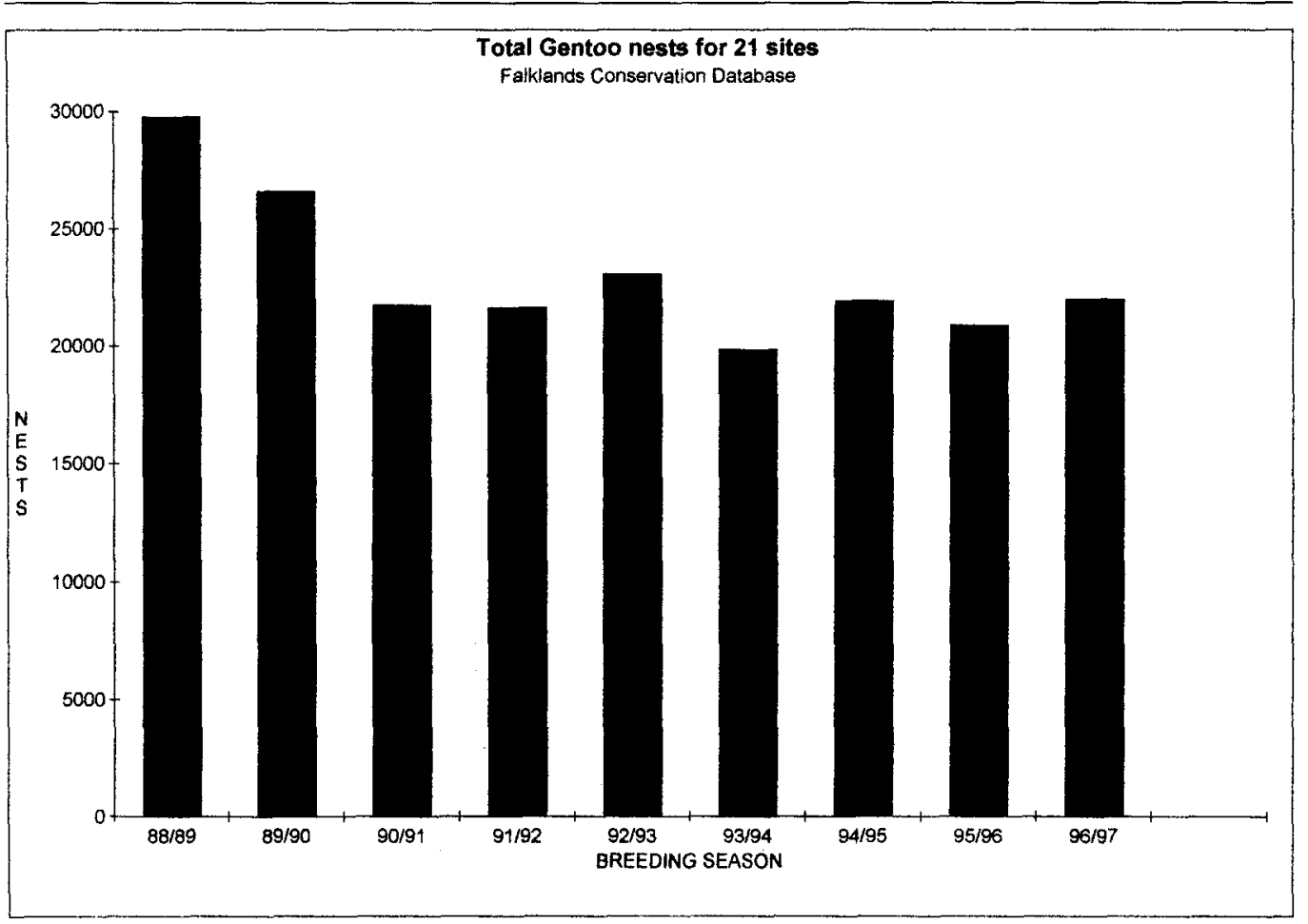

Figure 4. Gentoo population trends monitored for 21 sites since $1988 / 89$.

Site names and grid references: Bull Point UB4298/UB4399/UC3701; Volunteer Point VC4297/VC4693/VD3903; Berthas Beach VC0651; Fox Point VC0147; Cape Dolphin UD6717/UD6418/UD6817; Strike off Point VC 3384; Kidney Cove VC4779; Seal Bay VD2907; Fanning Harbour UC5597; Paloma Beach UD6101; Rookery Sands UD5400; Rookery Point UC5479; Port Edgar TC7524/TC7625; Long Point UC2497; Gladstone Valley UC2995; Little Mountain UD4005; Albemarle TC5910/TC6011; Carcass Bay UC0139/TC9938; Saunders Island TD7200/TD7801/TD8510; Sea Lion Island UB5989; Beaver Island TC0844.

Bennett gave no account of the methodology used, he stated that his figures were most likely to be underestimates, and did not include the large colonies on Beauchene and Bird Islands, which currently hold 28 per cent of the Falklands' population. It therefore appears that the Falklands population has declined to about 10 per cent of its 1932/33 level.

\section{Population changes}

Whereas populations of king penguins in the Falklands have increased in recent years, in line with world-wide trends, populations of gentoo and rockhopper penguins have decreased substantially over the last 60 years, perhaps by as much as 50 and 90 per cent,

Table 4. Gentoo population comparison

\begin{tabular}{lrr}
\hline Area & $1932 / 33$ & $1995 / 96$ \\
\hline East Falkland & 17,800 & 16,407 \\
West Falkland & 16,470 & 23,490 \\
Speedwell Island group & 6,150 & 2,555 \\
Bleaker Island & 1,600 & 875 \\
Lively Island & 2,400 & 490 \\
Sea Lion Island & 18,000 & 1,928 \\
Saunders \& Kepple Islands & 1,900 & 4,070 \\
Jason Islands & 35,000 & 6,119 \\
Passage Islands & 1,000 & 300 \\
Pebble Island & 1,000 & 754 \\
Carcass Island & 200 & 180 \\
New Island group & 2,500 & 5,100 \\
Weddell Island group & 12,000 & 2,112 \\
Total pairs & 116,020 & 64,380 \\
\hline
\end{tabular}

Sites are grouped into areas used by Bennett (1933).

(C) $1998 \mathrm{FFI}$, Oryx, $32(3), 223-232$ 


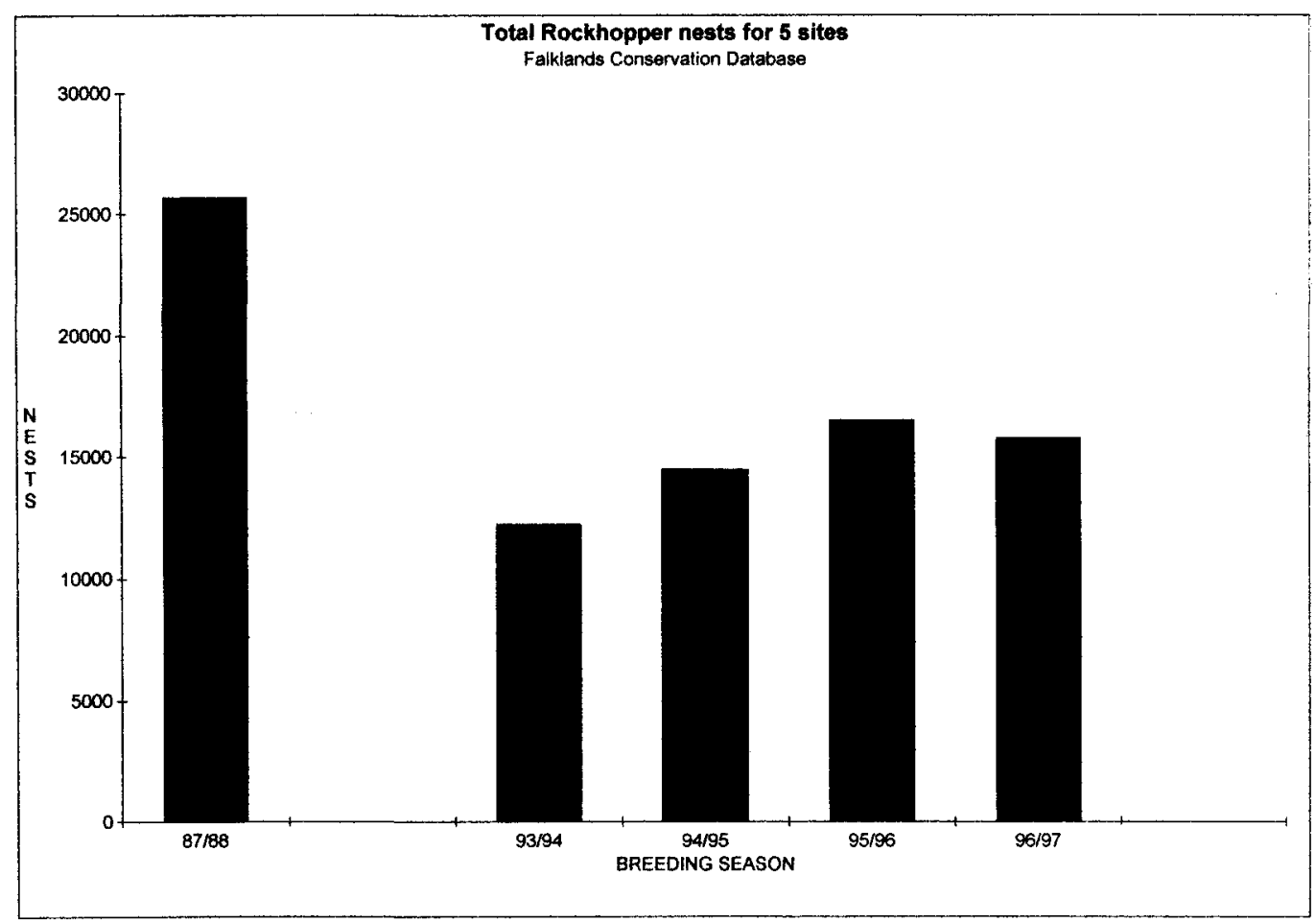

Figure 5. Rockhopper penguin population trends for five sites monitored since $1987 / 88$.

Site names and grid references: Berkeley Sound VC4189/VC4791/VC3688/VC3683/VC4382; Fanning Head UC5296/UC5297; Cape Bougainville UD9816; Westpoint Island TD4107/TD4205/TD4202; Saunders Island TD7611/TD6815.

respectively. This is supported by data from more recent site studies, which also suggest that the declines have continued into recent years. Kidney Island's rockhopper population declined from 3000 pairs in $1960 / 61$ to 240 pairs in 1994/95 (Bingham, 1995), rockhopper colonies at New Island declined from $>100,000$ pairs in $1976 / 78$ to 4000 pairs in 1992 (Thompson, 1993), and at Beauchene Island the colony had declined from 300,000 pairs in 1980 (Lewis-Smith and Prince, 1985) to 71,500 pairs in 1991 (Thompson, 1993). The 1985/86 summer season was especially bad for rockhoppers, with tens of thousands of adults dying from starvation during their annual moult. Analysis of carcasses showed that they had died from starvation, and this was likely to have resulted from food shortages prior to the moult (Keymer, 1988).

It is not easy to account for these declines.
Direct exploitation of penguins has diminished to insignificance. Killing birds to extract oil ceased at the beginning of the 20th century, and collecting of eggs for food has now declined to very low levels.

Commercial fisheries started around the Falklands in the 1960s, expanded greatly during the 1970s and 1980s, and in recent years have been generally stable after the Falkland Islands Government imposed a licensing regime in 1985 . There is some evidence that penguin population size and breeding performance are related to food availability around the Falklands (Keymer, 1988; Thompson, 1989, 1993; Bingham, 1995). There is no direct evidence that food availability to penguins has been affected by commercial fishing, but this possibility cannot be ruled out, especially in respect of squid fisheries, larval/juvenile squid being an important element of the diet of both 
Table 5. Rockhopper population comparison

\begin{tabular}{lrr}
\hline Area & $1932 / 33$ & $1995 / 96$ \\
\hline East Falkland & 153,500 & 20,552 \\
West Falkland & 24,200 & 12,973 \\
Kidney \& Cochon Islands & 12,000 & 615 \\
Sea Lion Island & 150,000 & 504 \\
Bleaker Island & 5,000 & 700 \\
West Point Island & 50,000 & 4,042 \\
Passage Islands & 10,000 & 392 \\
Pebble Island & 6,000 & 6,702 \\
Jason Islands & $2,625,000$ & 149,400 \\
New Island group & 130,000 & 8,972 \\
Saunders \& Kepple Islands & 3,400 & 6,949 \\
Beauchene Island & No survey & 74,300 \\
Bird Island & No survey & 10,600 \\
& & \\
Total pairs & $3,169,000$ & 297,000 \\
\hline
\end{tabular}

Sites are grouped into areas used by Bennett (1933).

rockhopper and gentoo penguins (Thompson, 1994). It should also be noted that the breeding season diet of rockhoppers appears to contain more euphausids and less commercially fished species than that of the gentoo (Thompson, 1993).

Loss or degradation of breeding habitat has probably occurred at some sites as a result of erosion, fire or other anthropogenic activity. Disturbance from humans and stock may also have been (and remain) a problem in some areas, although there is little firm evidence that this or the current level of tourist visits have any discernible influence. Overall, none of these effects can explain large-scale changes, especially at sites where breeding habitat loss and disturbance have been minimal or non-existent. There is also no evidence of increased impact from introduced predators, and many sites lack any introduced predatory species.

Rockhopper penguins (subspecies E. c. filholi) have declined very substantially in the New Zealand subantarctic islands since the 1940s (Cooper, 1992; Cunningham and Moors, 1994). At these sites also there was no evidence that land-based influences were responsible. It was therefore suggested that changes in the marine environment may have occurred and affected the survival of penguins, either directly through physical factors or, more likely, indirectly through changes to the food web. There is circumstantial evidence (Croxall, 1992, Fraser et al., 1992) that some broadscale changes in seabird populations may correlate with changes in Southern Ocean marine environments, at least insofar as these are indicated by increases in air and sea-surface temperature, which may be linked to changes in the location and/or magnitude of marine productivity. For such effects to have influenced Falkland Islands' penguins, the factors involved must operate to affect both resident inshore-feeding species such as gentoo penguins, and offshore-feeding migratory species such as rockhopper penguins. A very high research priority is to determine where rockhopper penguins forage when breeding and, in particular, where they reside outside the breeding season.

These data would also have great relevance in relation to the potential effects of oil exploration and extraction (the former scheduled to start in 1998), because penguins are highly vulnerable to oil pollution. Studies of distribution and foraging ecology at sea will need to be complemented by breeding population studies ashore, in particular to determine the relative contributions of changes in adult and juvenile survival to the overall population decline.

At a recent international workshop reviewing the status of penguins, it was clear that the large-scale declines in rockhopper penguin populations were of such magnitude as to justify treating the species as globally threatened (Vulnerable), according to the new IUCN criteria. A co-ordinated programme of research on this species at its most important population site, the Falkland Islands, is now long overdue.

\section{Acknowledgements}

My thanks go to the RAF Ornithological Society and other dedicated volunteers who assisted with the surveys, the Commander, British Forces Falkland Islands, for arranging logistical support and aerial photographs, and the Wellcome Trust for funding the project. Thanks to all the landowners who, virtually without exception, offered support in providing information, assistance and access to their lands. 


\section{References}

Bennett, A.G. 1933. The Penguin Population of the Falkland Islands in 1932/33. Government Press, Falkland Islands. 4pp.

Bingham, M. 1995. Population status of penguin species in the Falkland Islands. Penguin Conservation, 8 (1), 14-19.

Bingham, M. and Mejias, E. In press. Penguin populations of the Magellanic Region. Scientia Marina.

Cooper, W. 1992. Rockhopper Penguins at the Auckland Islands. Notornis, 39, 66-67.

Croxall, J.P. 1992 Southern ocean environmental change: effects on seabird, seal and whale populations. Philosophical Transactions of the Royal Society of London, B, 338, 319-328.

Croxall, J.P. and Rothery, P. 1995. Population change in gentoo penguins Pygoscelis papua at South Georgia: potential roles of adult survival, recruitment and deferred breeding. In Penguin Biology: Advances in Research and Management (eds P. Dann, I. Norman and P. Reilly), pp. 26-38. Surrey Beatty \& Sons, Chipping Norton, Australia.

Croxall, J.P., McInnes, S.J. and Prince P.A. 1984. The status and conservation of seabirds at the Falkland Islands. In Status and Conservation of the World's Seabirds. (eds J. P. Croxall, P. G. H. Evans and R. W. Schreiber), pp. 271-291. ICBP Technical Publication No. 2., ICBP, Cambridge, UK.

Cunningham, D.M. and Moors, P.J. 1994. The decline of rockhopper penguins Eudyptes chrysocome at Campbell Island, Southern Ocean and the influence of rising sea temperatures. Emu, 94, 27-36.

Fraser, W.R., Trivelpiece, W.Z., Ainley, D.G. and Trivelpiece, S.G. 1992. Increases in Antarctic penguin populations: reduced competition with whales or a loss of sea ice due to environmental warming? Polar Biology, 11, 525-531.

Keymer, I.F. 1988. An Investigation of Rockhopper Penguin Mortality in the Falklands during the 1985/86 Breeding Season. Falkland Islands Foundation Project Report, Falkland Islands. 19pp.

Lewis Smith, R.I. and Prince, P.A. 1985. The natural history of Beauchene Island, Falkland Islands. Biological Journal of the Linnean Society, 24, 233-283.

Lewis Smith, R.I. and Tallowin, J.R.B. 1979. The distribution and size of king penguin rookeries on South Georgia. British Antarctic Survey Bulletin, 49, 259-276.

Robertson, G. 1986. Population size and breeding success of the gentoo penguin at Macquarie Island. Australian Wildlife Research, 13, 583-587.

Thompson, K.R. 1989. An Assessment of the Potential for Competition between Seabirds and Fisheries in the Falkland Islands. Falkland Islands Foundation Project Report, Falkland Islands. 94pp.

Thompson, K.R. 1993. Falkland Islands Seabird Monitoring Programme Summary of Results. Falklands Conservation Report SMP/3, Falkland Islands. 25pp.

Thompson, K.R. 1994. Predation on Gonatus antarcticus by Falkland Islands seabirds. Antarctic Science, 6, 269-274.

Woehler, E.J. 1993. The Distribution and Abundance of Antarctic and Subantarctic Penguins. Scientific Committee on Antarctic Research, University Printing Services, Cambridge. 76pp.

Mike Bingham, PO Box 26, Falklands Conservation, Stanley, Falkland Islands.

Received 26 June 1997

Accepted 9 February 1998 